\title{
Glucagon-like peptide-1 (GLP-1) and glucose metabolism in human myocytes
}

\author{
M A Luque, N González, L Márquez, A Acitores, A Redondo, \\ M Morales, I Valverde and M L Villanueva-Peñacarrillo
}

Departamento Metabolismo, Nutrición y Hormonas, Fundación Jiménez Díaz, Avda Reyes Católicos 2, 28040 Madrid, Spain

(Requests for offprints should be addressed to M L Villanueva-Peñacarrillo; Email: mlvillanueva@fjd.es)

\begin{abstract}
Glucagon-like peptide-1 (GLP-1) has been shown to have insulin-like effects upon the metabolism of glucose in rat liver, muscle and fat, and on that of lipids in rat and human adipocytes. These actions seem to be exerted through specific receptors which, unlike that of the pancreas, are not - at least in liver and muscle - cAMP-associated. Here we have investigated the effect, its characteristics, and possible second messengers of GLP-1 on the glucose metabolism of human skeletal muscle, in tissue strips and primary cultured myocytes. In muscle strips, GLP-1, like insulin, stimulated glycogen synthesis, glycogen synthase $a$ activity, and glucose oxidation and utilization, and inhibited glycogen phosphorylase a activity, all of this at physiological concentrations of the peptide. In cultured myotubes, GLP-1 exerted, from $10^{-13} \mathrm{~mol} / \mathrm{l}$, a doserelated increase of the $\mathrm{D}-\left[\mathrm{U}_{-}{ }^{14} \mathrm{C}\right]$ glucose incorporation into glycogen, with the same potency as insulin, together with an activation of glycogen synthase $a$; the effect of $10^{-11} \mathrm{~mol} / \mathrm{l}$ GLP-1 on both parameters was additive to that induced by the equimolar amount of insulin. Synthase
\end{abstract}

a was still activated in cells after 2 days of exposure to GLP-1, as compared with myotubes maintained in the absence of peptide. In human muscle cells, exendin-4 and its truncated form 9-39 amide (Ex-9) are both agonists of the GLP-1 effect on glycogen synthesis and synthase a activity; but while neither GLP-1 nor exendin-4 affected the cellular cAMP content after 5-min incubation in the absence of 3-isobutyl-1-methylxantine (IBMX), an increase was detected with Ex-9. GLP-1, exendin-4, Ex-9 and insulin all induced the prompt hydrolysis of glycosylphosphatidylinositols (GPIs). This work shows a potent stimulatory effect of GLP-1 on the glucose metabolism of human skeletal muscle, and supports the long-term therapeutic value of the peptide. Further evidence for a GLP-1 receptor in this tissue, different from that of the pancreas, is also illustrated, suggesting a role for an inositolphosphoglycan (IPG) as at least one of the possible second messengers of the GLP-1 action in human muscle.

Journal of Endocrinology (2002) 173, 465-473

\section{Introduction}

Glucagon-like peptide-1 (GLP-1) is an incretin hormone which helps to regulate plasma glucose levels by not only enhancing pancreatic $\beta$-cell secretion (Montrose-Rafizadeh et al. 1994) and diminishing blood glucagon and somatostatin concentrations (Gutniak et al. 1992), but also by acting independently of the circulating insulin levels (Gutniak et al. 1992, D'Alessio et al. 1994, 1995). To improve glucose utilization, GLP-1 may have peripheral activity in insulin-sensitive tissues; in fact, some insulin-like effects of GLP-1 on glucose metabolism in liver and skeletal muscle have been shown by in vitro studies in normal (Valverde et al. 1994, Villanueva-Peñacarrillo et al. 1994) and diabetic (Morales et al. 1997) rats, such as the stimulation of glycogen synthesis, glycogen synthase a activity, and glucose oxidation and utilization.
In the adipose tissue of the rat, it was observed that GLP-1 not only exerts an action on lipid metabolism dose-dependently lipolytic and/or lipogenic (Ruiz-Gande et al. 1992, Perea et al. 1997) - but also, as in liver and muscle, that it stimulates parameters involved in glucose metabolism (Perea et al. 1997).

In liver (Villanueva-Peñacarrillo et al. 1995a), muscle (Delgado et al. 1995, Villanueva-Peñacarrillo et al. 1995b, Yang et al. 1998) and fat (Mérida et al. 1993, Valverde et al. 1993), GLP-1 seems to act through specific receptors, apparently different - at least in liver and muscle - in structure or signaling pathway from that in the pancreas, which is cAMP-associated (Thorens 1992). An inositolphosphoglycan (IPG) has already being proposed as one of the possible second messengers in the GLP-1 effect in these tissues, by studies in $\mathrm{BC}_{3} \mathrm{H}$ myocytes (Galera et al. 1996), HEP hepatoma cells (Trapote et al. 1996) and rat hepatocytes and adipocytes (Márquez et al. 1998). 
In this work, we have studied the effects, characteristics, and possible mechanisms of action, of GLP-1 upon muscle glucose metabolism in man.

\section{Materials and Methods}

\section{Chemicals}

Human GLP-1 (7-36)amide (GLP-1, Bachem AG, Bubendorf, Switzerland); pork insulin (Novo Biolabs, Bagsvaerd, Denmark); exendin 1-39 amide (Ex-4) and exendin 9-39 amide (Ex-9) were gifts from Dr John Eng (VAMC, New York, NY, USA); HAM's F-10, fetal bovine serum (FBS) and $\alpha$-MEM ( $\alpha$-modified Eagle medium Biochrom KG, Berlin, Germany); dexamethasone, bovine serum albumin, fraction $\mathrm{V}$ (BSA), penicillinstreptomycin, trypsin, EDTA, collagen from rat tail and glutamine (Sigma Chemical Co., St Louis, MO, USA); D- $\left[\mathrm{U}_{-}{ }^{14} \mathrm{C}\right]$ glucose and $\mathrm{D}-\left[5-{ }^{3} \mathrm{H}\right]$ glucose (Amersham, Chalfont, Bucks, UK); trichloroacetic acid (TCA, Merck, Darmstadt, Germany); human epidermal growth factor (hEGF) and amphotericin B (Clonetics, Palo Alto, CA, USA); D-glucose anhydrous (Scharlau, Barcelona, Spain); $\mathrm{HCl}$ (Panreac, Barcelona, Spain); myo- $\left[1-{ }^{3} \mathrm{H}\right]$ inositol and EN ${ }^{3} \mathrm{HANCE}$ (Du Pont NEN, Boston, MA, USA); skeletal muscle cell basal medium (SKBM, Promocell, Heidelberg, Germany); fetuin FBS (CalbiochemNovabiochem, Darmstadt, Germany); gentamicin (Lab. Normon, S.A., Madrid, Spain); hyamine hydroxide (Hopkins and Williams, Chendewell Health, Essex, UK); ${ }^{3} \mathrm{HOH}$ and $\mathrm{cAMP}\left[{ }^{125} \mathrm{I}\right] \mathrm{RIA}$ kits (NEN Du Pont Co., Brussels, Belgium); Ultima Gold scintillation liquid (Packard, Gröningen, The Netherlands).

\section{Biological material}

Human vastus lateralis and cremaster muscle pieces were obtained from normal-weight subjects (BMI $<26 \mathrm{~kg} / \mathrm{m}^{2}$ ) undergoing Richard's and inguinal hernia surgery respectively. The consent was obtained from the subjects after the nature of the procedure was explained, and the study was approved by the Ethic Committee of the Fundación Jiménez Díaz, Madrid, in accordance with the guidelines proposed in The Declaration of Helsinki.

\section{Cell culture}

After removal, vastus lateralis tissue $(\approx 100 \mathrm{mg})$ was immediately transported to the laboratory in HAM's F-10. The isolation of myoblasts was performed as described previously with minor modifications (Blau \& Webster 1981, Henry et al. 1995). Muscle was cleaned of blood with HAM's F-10, dissected from visible connecting tissue, and then subjected to digestion, in sterile conditions, by three consecutive treatments of $20 \mathrm{~min}$, each with trypsin-EDTA $(0 \cdot 05 \%-0 \cdot 02 \%, \mathrm{w} / \mathrm{v})$, at room temperature; after every treatment, dispersed cells were collected in HAM's F-10 and kept at $4{ }^{\circ} \mathrm{C}$. When tissue dispersion was completed, 10\% FBS (v/v) was added, and cells were then sedimented at $900 \boldsymbol{g}$ for 4 min and finally resuspended in $5 \mathrm{ml}$ SKGM growing medium (SKBM with added $10 \mathrm{ng} / \mathrm{ml} \mathrm{hEGF,} 0.5 \mathrm{mg} / \mathrm{ml}$ fetuin FBS, $0.39 \mu \mathrm{g} / \mathrm{ml}$ dexamethasone, $0.5 \mathrm{mg} / \mathrm{ml} \mathrm{BSA}, 50 \mu \mathrm{g} / \mathrm{ml}$ gentamicin, $50 \mathrm{ng} / \mathrm{ml}$ amphotericin $\mathrm{B}, \quad 50 \mathrm{UI} / \mathrm{ml}-$ $50 \mu \mathrm{g} / \mathrm{ml}$ penicillin-streptomycin, $2 \% \mathrm{FBS}$ ). To reduce the number of fibroblasts, dispersed tissue was placed in a $100 \mathrm{~mm}$ diameter collagen-free well and kept for $20 \mathrm{~min}$ at $37^{\circ} \mathrm{C}$. The non-attached cells were seeded in a rat collagen-treated $75 \mathrm{~cm}^{2}$ flask (Costar Co., Cambridge, MA, USA), and cultured at $37^{\circ} \mathrm{C}$ in SKGM growing medium until reaching $\approx 80 \%$ confluence (4-6 weeks), the medium being exchanged every 3 days. After gentle trypsinization ( $0.025 \%$ trypsin-0.01\% EDTA, w/v), cells were quantified and newly seeded in six-well culture slides at a density of 20000 cells/well, and further cultured until 70-80\% confluence (4-6 weeks); then the growing medium was substituted by that for fusion, consisting of $\alpha$-MEM with added 2\% FBS, $1 \%$ penicillin-streptomycin $(\mathrm{v} / \mathrm{v})$ and $2 \%$ glutamine, and cells were further cultured until differentiation into myotubes occurred (3-4 days).

Before and after the differentiation process, part of the wells from some of the cell cultures were kept at $-70{ }^{\circ} \mathrm{C}$ for determination of changes in creatinine kinase activity (Gerhardt 1983), which represented an increase from $43 \pm 9 \mathrm{U} / \mathrm{g}$ protein to $116 \pm 15 \mathrm{U} / \mathrm{g}(n=6$ from three subjects) after fusion.

\section{Glycogen synthase a and glycogen phosphorylase a activities}

The methods used were those already described in detail for rat hepatocytes (Valverde et al. 1994) and skeletal muscle (Villanueva-Peñacarrillo et al. 1994). Cremaster muscle strips (four to six per each muscle), after 30-min pre-incubation at $37^{\circ} \mathrm{C}$ in Krebs-Ringer bicarbonate (KRB) buffer containing 1\% BSA and $5 \mathrm{mmol} / 1$ $\mathrm{D}$-glucose, were incubated for $10 \mathrm{~min}$ at $37^{\circ} \mathrm{C}$ in the same medium as above, and in the absence and presence of peptides; always, at least one of the muscle strips of each subject was incubated in the absence of peptides for paired control. Primary culture cells from each subject were incubated for $10 \mathrm{~min}$ in $1 \mathrm{ml} \alpha$-MEM, in the absence (for paired control) or presence of peptides. The cells or tissue samples were immediately homogenized and frozen until the enzymatic activities were assayed as by Hue et al. (1975), except for the final glycogen extraction, which was done according to Fleig et al. (1984).

\section{Glycogen synthesis, ${ }^{14} \mathrm{CO}_{2},{ }^{3} \mathrm{HOH}$ and lactate production} D-[U- $\left.{ }^{14} \mathrm{C}\right]$ glucose incorporated into glycogen, ${ }^{14} \mathrm{CO}_{2}$ and ${ }^{3} \mathrm{HOH}$ release, and lactate production, were measured 
simultaneously in the same cremaster muscle experimental samples.

Cremaster muscle strips, after 30-min pre-incubation at $37^{\circ} \mathrm{C}$ in $1.5 \mathrm{ml} \mathrm{KRB}$ containing $1 \% \mathrm{BSA}$ and $5 \mathrm{mmol} / 1$ D-glucose, were incubated for $60 \mathrm{~min}$ in the same medium with $0.35 \mu \mathrm{Ci}$ D-[U- $\left.{ }^{14} \mathrm{C}\right]$ glucose and $0.3 \mu \mathrm{Ci}$ $\mathrm{D}-\left[5-{ }^{3} \mathrm{H}\right]$ glucose, and in the presence of peptides, as described previously (Morales et al. 1997); at least one of the strips from each subject, serving as paired control, was incubated in the absence of peptide. Primary culture myocytes from each subject were incubated for $60 \mathrm{~min}$ at $37^{\circ} \mathrm{C}$ in $250 \mu \mathrm{l} \alpha$-MEM, containing $1.5 \mu \mathrm{Ci}$ $\mathrm{D}-\left[\mathrm{U}-{ }^{14} \mathrm{C}\right]$ glucose, and in the absence (for paired control) and presence of peptides. In both tissue and cells, the $\mathrm{D}-\left[\mathrm{U}-{ }^{14} \mathrm{C}\right]$ glucose incorporated into glycogen was extracted and determined according to the procedure described by Cuendet et al. (1976).

To measure ${ }^{14} \mathrm{CO}_{2}$ and ${ }^{3} \mathrm{HOH}$ in cremaster muscle strips, the basic procedure described in detail elsewhere (Cámara et al. 1991) was followed. In brief, two cups with cellulose Whatman paper, one containing $0.5 \mathrm{ml} 0.1 \mathrm{~mol} / 1$ $\mathrm{HCl}$ for ${ }^{3} \mathrm{HOH}$ uptake, were hung from the rubber stopper vial during the incubation period. Then, $250 \mu \mathrm{l}$ hyamine hydroxide were injected into the second cup, for ${ }^{14} \mathrm{CO}_{2}$ uptake; after $3 \mathrm{~min}$ at $4{ }^{\circ} \mathrm{C}$, the muscle tissue was removed, and the vials with the cups were maintained at $37^{\circ} \mathrm{C}$ for $30 \mathrm{~min}$ followed by $60 \mathrm{~min}$ at $25^{\circ} \mathrm{C}$; then the cups were placed separately in $5 \mathrm{ml}$ of scintillation liquid for ${ }^{3} \mathrm{H}$ and ${ }^{14} \mathrm{C}$ content measurements. To control the ${ }^{3} \mathrm{HOH}$ recovery, $1.5 \mathrm{ml}$ of the same medium containing $4 \mathrm{nCi}{ }^{3} \mathrm{HOH}$ (NEN Du Pont Co., Brussels, Belgium), without tissue, underwent the whole procedure in each experimental set. Double-channel counting indicated the absence of cross-contamination. The lactate content in the incubation medium was enzymatically assayed (Hohorst 1965).

\section{cAMP}

Primary culture myocytes were incubated for 5 and $30 \mathrm{~min}$ at $37^{\circ} \mathrm{C}$ in $500 \mu \mathrm{l} \alpha$-MEM, in the absence of 3-isobutyl-methylxantine (IBMX), and in the absence (control) and presence of peptides, following the procedure already described for rat hepatocytes (Valverde et al. 1994).

\section{IPGS}

IPGs were measured indirectly (Saltiel et al. 1986) as the hydrolysis of glycosylphosphatidylinositols (GPIs). Primary culture myocytes $\left(2 \times 10^{4}\right.$ cells per well) from each subject were pre-labeled, for $60 \mathrm{~min}$ at $37^{\circ} \mathrm{C}$, with $0.2 \mu \mathrm{Ci}$ myo- $\left[{ }^{3} \mathrm{H}\right]$ inositol in $0.75 \mathrm{ml} \alpha$-MEM with added $0 \cdot 1 \%$ BSA, $1 \%$ glutamine and $1 \%$ antibiotics; the radioactive medium was then removed and cells were incubated in fresh $\alpha$-MEM for different time periods $(0 \cdot 5-10 \mathrm{~min})$ in the absence (control) and presence of peptides. Incubation was interrupted by addition of $10 \%$ TCA at $4{ }^{\circ} \mathrm{C}$, and the radioactive GPI content was extracted and determined in the respective precipitates, as previously described in detail (Márquez et al. 1998).

\section{Statistical study}

Results are expressed as means \pm S.E.M., together with the number of observations. The statistical significance $(P<0 \cdot 05)$ of the increments was assessed by the Student's $t$-test and, in some cases, by one-way ANOVA and, when statistically significant $(P<0 \cdot 05)$, it was followed by the least significant differences (LSD) test for post hoc multiple comparisons, using the SPSS statistical software.

\section{Results}

\section{Glucose metabolism}

Table 1 shows the respective control value of glycogen synthesis, glycogen synthase $a$ and phosphorylase $a$ activities, and glucose oxidation and utilization, in human cremaster muscle strips, as well as the effect of GLP-1 and insulin on these parameters, expressed as percentage of the paired control obtained in the absence of peptide. As already reported in rat skeletal muscle (VillanuevaPeñacarrillo et al. 1994), GLP-1 significantly increased the $\mathrm{D}-\left[\mathrm{U}_{-}{ }^{14} \mathrm{C}\right]$ glucose incorporation into glycogen at $10^{-10} \mathrm{~mol} / \mathrm{l}$, as did $10^{-9} \mathrm{~mol} / 1$ insulin; the rise in glycogen synthesis by GLP-1 was accompanied by an increase in glycogen synthase $a$ and a reduction in glycogen phosphorylase a activities, and by a stimulation of glucose oxidation $\left({ }^{14} \mathrm{CO}_{2}\right.$ produced from $\mathrm{D}-\left[\mathrm{U}_{-}{ }^{14} \mathrm{C}\right]$ glucose) and utilization (tritiated water from $\mathrm{D}-\left[5-{ }^{3} \mathrm{H}\right]$ glucose, and lactate release), all this to a magnitude equivalent to the effect induced by insulin.

Figure 1A represents the effect of GLP-1 and that of insulin on the incorporation of $\mathrm{D}-\left[\mathrm{U}_{-}{ }^{14} \mathrm{C}\right]$ glucose into glycogen in human myotubes, expressed as percentage of the paired control value obtained within the same cell preparation in the absence of peptide. GLP-1 caused a concentration-related stimulation of the glycogen synthesis from $10^{-13} \mathrm{~mol} / \mathrm{l}$ of the peptide, which was already significant, and maximal, at $10^{-10} \mathrm{~mol} / \mathrm{l}$, and also statistically significant thereafter up to $10^{-7} \mathrm{~mol} / \mathrm{l}$ GLP-1. Unlike in previous observations in rat skeletal muscle (Villanueva-Peñacarrillo et al. 1994), the potency of GLP-1 at exerting glycogenic action in human muscle cells was, qualitatively and quantitatively, apparently indistinguishable from that of insulin; however, in this group of experiments, the cells showed a trend toward a modest desensitization in response to GLP-1 at $10^{-7} \mathrm{~mol} / \mathrm{l}$. In cells from one subject, the magnitude of the effect on glycogen synthesis of $10^{-10} \mathrm{~mol} / 1$ GLP-1 and $10^{-10} \mathrm{~mol} / 1$ insulin, tested in combination (Fig. 1B), was 
Table 1 Effect of glucagon-like peptide-1 (GLP-1) and insulin on glycogen synthesis and glucose metabolism in strips of normal human skeletal muscle (mean \pm S.E.M. ( $n=$ number of observations from 16 subjects))

G-synthesis
One-way ANOVA, $P=0 \cdot 011$
G-synthase a
One-way ANOVA, $P=0 \cdot 030$
G-phosphorylase a
One-way ANOVA, $P=0 \cdot 028$
${ }^{14} \mathrm{CO}_{2}$
One-way ANOVA, $P=0 \cdot 001$
${ }^{3}$ HOH
One-way ANOVA, $P=0 \cdot 016$
Lactate
One-way ANOVA, $P=0.032$

\section{Control}

No peptide

$5 \cdot 7 \pm 3 \cdot 3(9) \mathrm{nmol} / \mathrm{mg}$ protein

LSD test, vs control

$1 \cdot 3 \pm 0 \cdot 3(22) \mathrm{U} / \mathrm{g}$ protein

LSD test, vs control

$206 \pm 30(36) \mathrm{U} / \mathrm{g}$ protein

LSD test, vs control

$143 \pm 24$ (14) $\mathrm{pmol} / \mathrm{mg}$ protein

LSD test, vs control

$51 \pm 8(19) \mathrm{nmol} / \mathrm{mg}$ protein

LSD test, vs control

$68 \pm 11(10) \mu \mathrm{mol} / \mathrm{g}$ protein

LSD test, vs control
$\%$ of paired control

\begin{tabular}{|c|c|c|}
\hline \multicolumn{2}{|l|}{ GLP-1 } & \multirow{2}{*}{$\begin{array}{l}\text { Insulin } \\
10^{-9} \mathrm{~mol} / \mathrm{l}\end{array}$} \\
\hline $10^{-10} \mathrm{~mol} / \mathrm{l}$ & $10^{-9} \mathrm{~mol} / \mathrm{l}$ & \\
\hline $129 \pm 5(7)$ & $111 \pm 7(8)$ & $123 \pm 9(7)$ \\
\hline$P=0.002$ & $P=0 \cdot 205$ & $P=0.013$ \\
\hline $135 \pm 22(7)$ & $147 \pm 14(17)$ & $148 \pm 16$ \\
\hline$P=0.137$ & $P=0 \cdot 010$ & $P=0.010$ \\
\hline $76 \pm 13(12)$ & $86 \pm 5(23)$ & $83 \pm 6(30)$ \\
\hline$P=0 \cdot 010$ & $P=0.067$ & $P=0 \cdot 016$ \\
\hline $168 \pm 14(6)$ & - & $134 \pm 12$ \\
\hline$P<0.0001$ & & $P=0.024$ \\
\hline $134 \pm 17(10)$ & $148 \pm 11$ & $131 \pm 10$ \\
\hline$P=0.024$ & $P=0.004$ & $P=0.024$ \\
\hline $125 \pm 11(9)$ & - & $134 \pm 13(9)$ \\
\hline$P=0.061$ & & $P=0 \cdot 013$ \\
\hline
\end{tabular}

indistinguishable from the respective stimulated values obtained by each peptide individually; however, at $10^{-11} \mathrm{~mol} / \mathrm{l}$, this combination induced an increment of the control which was almost the sum of those exerted by each individual hormone.

GLP-1 also induced a small but highly significant increment $\left(P<0 \cdot 001\right.$ at $10^{-10}$ and $\left.10^{-9} \mathrm{~mol} / \mathrm{l}\right)$ in the glycogen synthase a activity paired control value $(28.0 \pm 3.3 \mathrm{mU} / \mathrm{g}$ protein, $n=57$ from nine subjects). Although this effect of the peptide when tested at $10^{-10} \mathrm{~mol} / \mathrm{l}$ was equal in magnitude to that induced by the equimolar amount of insulin, at $10^{-9} \mathrm{~mol} / 1(54 \pm 9 \%$ $\Delta$ of control, $n=29, P<0 \cdot 01)$ it was shown to be significantly higher $\left(P<0 \cdot 01\right.$ vs $10^{-9} \mathrm{~mol} / 1$ insulin: $22 \pm 5 \% \Delta$, $n=9, P<0 \cdot 01$ vs control). When GLP-1 and insulin were tested in combination in myocytes from one subject (Fig. $1 \mathrm{C}$ ), both at $10^{-10} \mathrm{~mol} / \mathrm{l}$, the value obtained was not different from those produced by each individual hormone; yet, the increment induced by the combination of both at $10^{-11} \mathrm{~mol} / 1$ represented the sum of those exerted by each hormone.

\section{Prolonged GLP-1 action}

To learn about the effect of a prolonged action of GLP-1 upon glycogen metabolism in the skeletal muscle, we measured the glycogen synthesis and glycogen synthase a activity in primary culture myocytes from two subjects, after $48 \mathrm{~h}$ of culture in $\alpha$-MEM in the absence and presence of added $10^{-7} \mathrm{~mol} / \mathrm{l}$ GLP-1 or insulin. To correct the loss of stability of the hormones during the experimental conditions, mainly that of GLP-1 (previously estimated at $35 \cdot 6 \pm 2 \cdot 1 \%$ radioactive $10^{-7} \mathrm{~mol} / \mathrm{l}$ GLP-1 degradation after $10 \mathrm{~h}$ in the presence of cells, $n=6$, by measuring the $10 \%$ TCA-precipitable peptide), the medium without or with GLP-1 or insulin was replaced by a fresh one every $8 \mathrm{~h}$. As a result, we observed that after a 2-day treatment with GLP-1, the D-[U- $\left.{ }^{14} \mathrm{C}\right]$ glucose incorporated into glycogen was $41 \pm 8 \%$ higher $(n=13$, $P<0 \cdot 001)$ with respect to the control value obtained in cells maintained in culture without peptide $(14.4 \pm 0.5 \mathrm{nmol}$ glucose $/ \mathrm{mg}$ protein, $n=12) ; \quad$ this increment was much lower $(P<0 \cdot 001)$ though than that detected after 2 days in the presence of insulin $(137 \pm 10 \%$ $\Delta$ of control, $n=15, P<0 \cdot 001)$. Also, after either GLP-1 or insulin treatment, an increase of the control glycogen synthase $a$ activity $(78 \pm 4 \mathrm{mU} / \mathrm{g}$ protein, $n=9)$, although very modest, was observed ( $17 \pm 6 \% \Delta$ of control, $n=20$, and $19 \pm 7 \% \Delta, n=16$, GLP-1 and insulin respectively, both $P<0 \cdot 02$ ).

\section{Characterization of GLP-1 receptor}

In an approach to characterize the GLP-1 effect on human muscle glucose metabolism, we tested in primary culture myocytes the action of Ex-4, and that of its truncated form, Ex-9 - agonist and antagonist, respectively, of the GLP-1 receptors in several cell systems - upon glycogen synthesis and synthase $a$ activity, and also their interaction with GLP-1. Ex-4, at $10^{-10} \mathrm{~mol} / 1$ (Fig. 2A), induced an increment $(74 \pm 13 \% \Delta$ of paired control, $n=21$ from four subjects) of the glycogen synthesis, equivalent to that exerted by the equimolar amount of GLP-1 $(73 \pm 8 \% \Delta$, $n=73$ from ten subjects). Surprisingly, in these cells, $10^{-10} \mathrm{~mol} / 1 \mathrm{Ex}-9$ also increased glycogen synthesis, to a magnitude ( $45 \pm 10 \% \Delta, n=34$ from six subjects) equal to that exerted by either GLP-1 or Ex-4. In previous studies using the same exendin batches as in this work, we have documented that Ex-9, when intravenously infused in rats, inhibits the insulinotropic effect of GLP-1 (Cancelas et al. 2001a), whereas Ex-4 stimulates insulin secretion (Cancelas et al. 2001b). When tested together, the effect of 

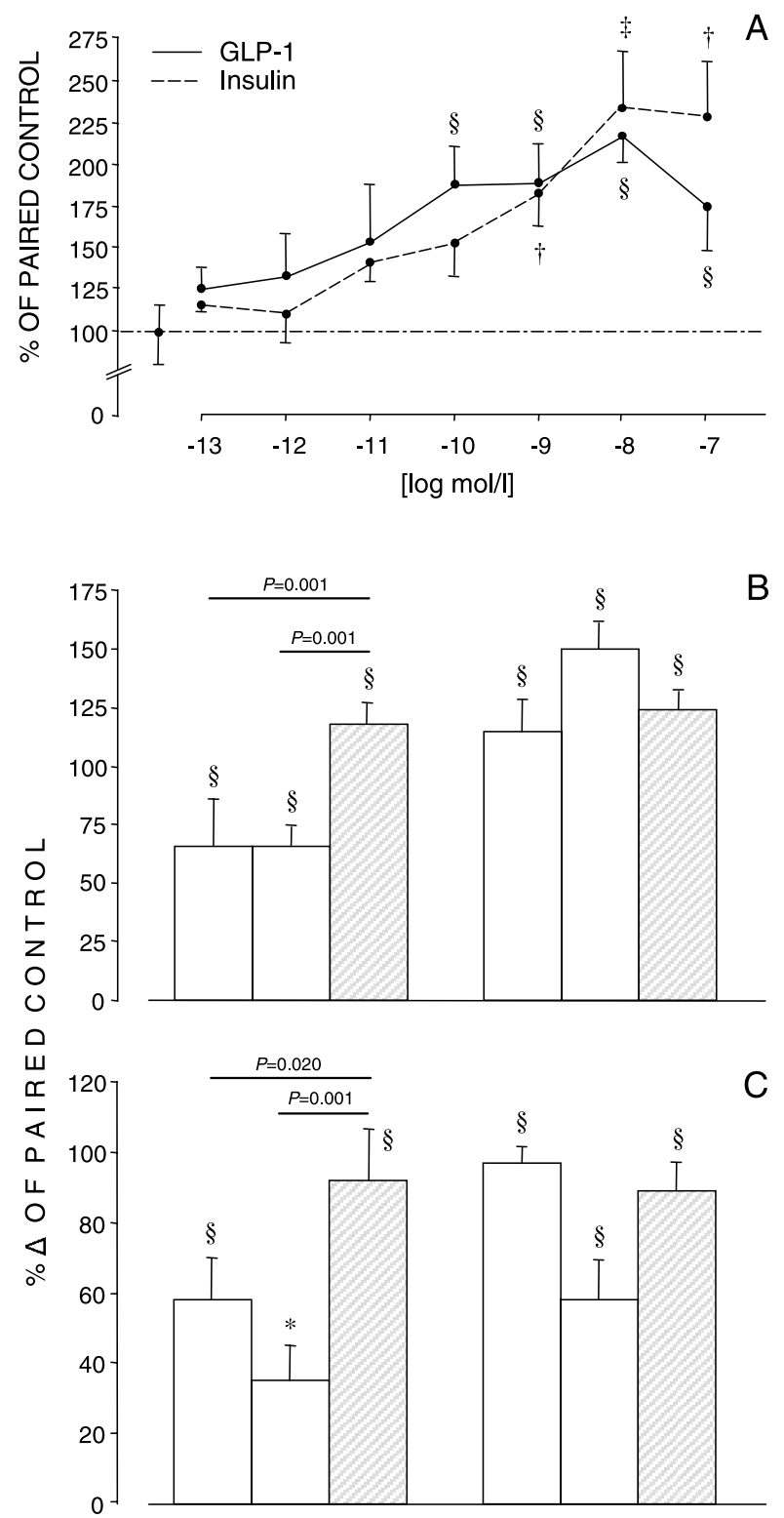

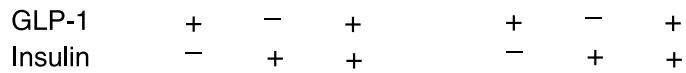

$$
\begin{aligned}
& 10^{-11} \mathrm{~mol} / \mathrm{l} \quad 10^{-10} \mathrm{~mol} / /
\end{aligned}
$$

Figure 1 Effect of glucagon-like peptide-1 (GLP-1) and insulin on glycogen synthesis and glycogen synthase a activity in primary cultured myocytes. (A) Dose-response of glycogen synthesis $(n=3-15)$ in cells from four subjects; (B) combined effect of GLP-1 and insulin on glycogen synthesis $(n=8-18)$, and (C) glycogen synthase a activity $(n=3-6)$. Values (mean \pm S.E.M.) are relative to the respective paired control obtained in the absence of peptide (A: $6 \cdot 8 \pm 1 \cdot 2 \mathrm{nmol} / \mathrm{mg}$ protein, $n=19$ from four subjects; B: $4 \cdot 9 \pm 0 \cdot 3 \mathrm{nmol} / \mathrm{mg}$ protein, $n=6$ from one subject; C: $29 \cdot 0 \pm$ $2.6 \mathrm{mU} / \mathrm{g}$ protein, $n=6$ from one subject). One-way ANOVA: (A) GLP-1, $P=0 \cdot 001$; insulin, $P<0.0001$; (B) $P<0.0001$; (C) $P<0.0001$. LSD test: vs control, ${ }^{*} P<0 \cdot 05,+P<0 \cdot 01, \neq P<0 \cdot 001, \S P<0 \cdot 0001$; significance between increments are indicated on the Figure.

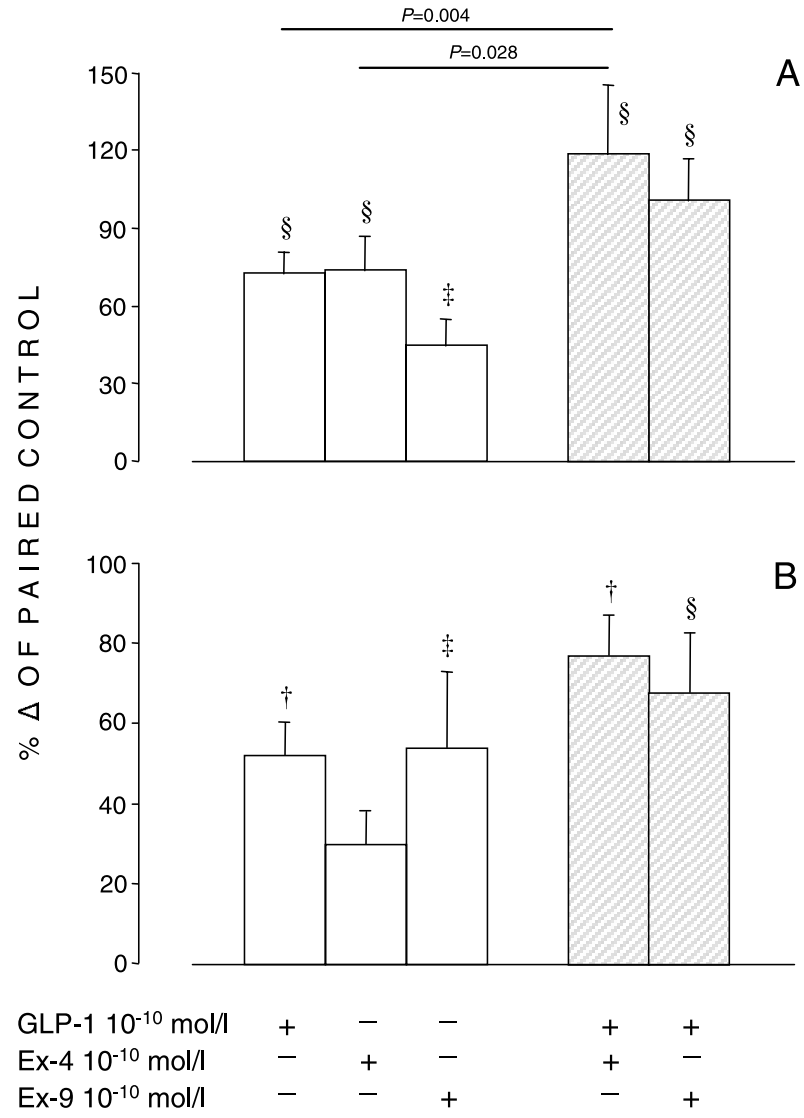

Figure 2 Effect of exendin (Ex)-4 and Ex-9, alone and in combination with GLP-1, on (A) glycogen synthesis in primary cultured myocytes $(n=21-73)$ from 12 subjects and (B) glycogen synthase a activity $(n=4-15)$ from six subjects. Values (mean \pm S.E.M.) are relative to the respective paired control obtained in the absence of peptide (A: $8 \cdot 8 \pm 0.9 \mathrm{nmol} / \mathrm{mg}$ protein, $n=64$ from 12 subjects; $B: 41 \pm 3 \mathrm{mU} / \mathrm{g}$ protein, $n=42$ from six subjects). One-way ANOVA: (A) $P<0 \cdot 0001 ;(B), P=0 \cdot 001$. LSD test vs control: $† P<0 \cdot 01, \ddagger P<0 \cdot 001, \S P<0 \cdot 0001$; significance between increments are indicated on the figure.

GLP-1 combined with Ex-4 $(119 \pm 27 \% \Delta, n=24$ from six subjects) or Ex-9 $(101 \pm 16 \% \Delta, n=40$ from six subjects), was higher than either individual value. The same characteristics of the action of both exendins in glycogen synthesis were detected upon glycogen synthase $a$ activity (Fig. 2B), the Ex-9 stimulating effect ( $54 \pm 19 \% \Delta$ of paired control, $n=16$ from three subjects) being similar to that induced by either GLP-1 ( $52 \pm 8 \% \Delta, n=15$ from three subjects) or Ex-4 (30 $\pm 8 \% \Delta, n=8$ from four subjects); in this case also, the effects of GLP-1 combined with Ex-4 (77 $\pm 10 \% \Delta, n=4$ from three subjects) or with Ex-9 $(68 \pm 14 \% \Delta, n=10$ from three subjects) were both higher than the respective individual ones, as observed in glycogen synthesis, but the differences did not achieve statistical significance. 
Table 2 Effect of $10^{-8} \mathrm{~mol} / \mathrm{I}$ GLP-1, Ex-4 or Ex-9 on the cAMP content in primary culture human myotubes $($ mean \pm S.E.M. $(n=$ number of observations from one subject)). One-way ANOVA, $P<0 \cdot 0001$

\begin{tabular}{|c|c|c|c|c|}
\hline \multicolumn{3}{|c|}{$5 \mathrm{~min}$} & \multicolumn{2}{|l|}{$30 \mathrm{~min}$} \\
\hline & Control & $\%$ of paired control & Control & $\%$ of paired control \\
\hline \multirow{3}{*}{ GLP-1 } & \multicolumn{2}{|c|}{$42 \pm 2 \mathrm{pmol} / \mathrm{mg}$ protein $(9)$} & \multicolumn{2}{|c|}{$77 \pm 6 \mathrm{pmol} / \mathrm{mg}$ protein $(10)$} \\
\hline & & $114 \pm 7(11)$ & & $60 \pm 6(12)$ \\
\hline & LSD test, vs control & $\begin{array}{l}P=0.068 \\
84 \pm 5(6)\end{array}$ & LSD test, vs control & $P<0.0001$ \\
\hline \multirow{3}{*}{ Ex-9 } & LSD test, vs control & $P=0.040$ & LSD test, vs control & $P=0.024$ \\
\hline & & $131 \pm 6$ & & $61 \pm 5(6)$ \\
\hline & LSD test, vs control & $P=0.001$ & LSD test, vs control & $P<0 \cdot 0001$ \\
\hline
\end{tabular}

To search for possible second messengers in the GLP-1 action in human muscle glucose metabolism, and also in that of exendins, we measured the cellular cAMP content in primary culture myocytes from one subject, incubated in the absence and presence of GLP-1, Ex-4 or Ex-9, for 5 or $30 \mathrm{~min}$, and also their effect, and that of insulin, on IPG generation from the hydrolysis of GPIs, in cell samples from three subjects. We observed (Table 2) no changes in the cellular cAMP control content after $5 \mathrm{~min}$ in the presence of $10^{-8} \mathrm{~mol} / \mathrm{l}$ GLP-1, but a clear decrease of the respective control value was demonstrated after a 30-min incubation period; with the equimolar amount of Ex-4, a statistically significant reduction, although small, of the cAMP content was already detected at 5 min of incubation and was still observed at $30 \mathrm{~min}$. Unlike Ex-4, Ex-9 exhibited a clear increase in the cellular cAMP content after $5 \mathrm{~min}$ of incubation, which fell below the control value at $30 \mathrm{~min}$.

For cellular GPI content, as the values obtained in primary culture myocytes from three subjects incubated in the absence of added peptides from 0.5 to $10 \mathrm{~min}$ did not show statistical difference at any time point, the mean of these values was used as control. GLP-1, at $10^{-9} \mathrm{~mol} / \mathrm{l}$, induced a rapid decrease of the radioactive GPIs (Fig. 3A), already detected in the first $30 \mathrm{~s}$ in the presence of the peptide, and statistically significant at $1 \mathrm{~min}$; this reduction was followed by a progressive recovery of the control level, with a maximal apparent value at $10 \mathrm{~min}$. The dynamic in GPI content, induced by GLP-1, was similar to that observed with the equimolar amount of insulin. Ex-4 and Ex-9 at $10^{-9} \mathrm{~mol} / 1$ both exerted, like GLP-1, a rapid reducing effect on myotube GPI content, observed at $0 \cdot 5-$, 1 - and 2-min incubation in the presence of either peptide, which was followed by a recovery of the control value at $10 \mathrm{~min}$.

\section{Discussion}

The present data document that GLP-1 exerts insulin-like effects upon glucose metabolism in human skeletal

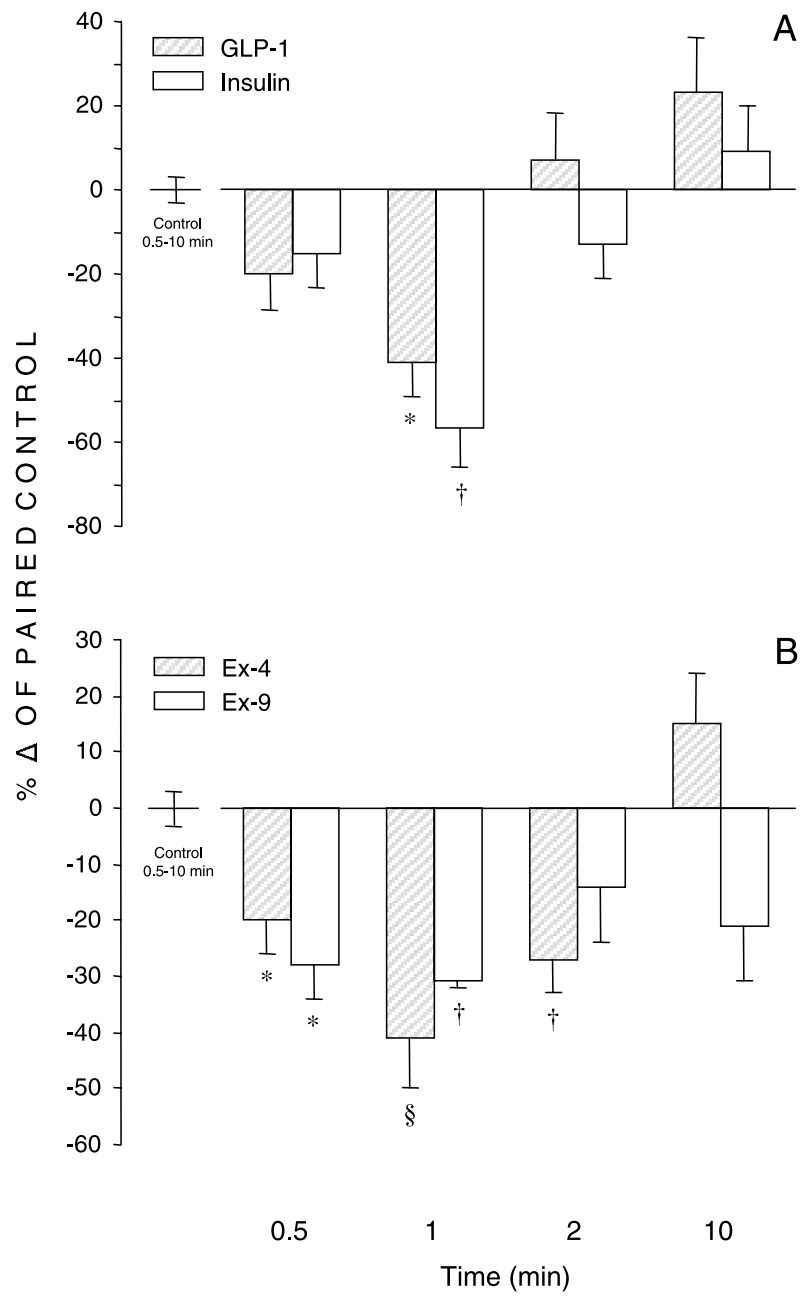

Figure $3 \mathrm{Effect}$ of $10^{-9} \mathrm{~mol} / \mathrm{l} \mathrm{GLP}-1$ or insulin (A), and that of Ex-4 or Ex-9 (B) on the hydrolysis of glycosylphosphatidylinositols (GPIs) in primary cultured myocytes. Values (mean \pm S.E.M., $n=3$ from three subjects) are relative to the respective paired control obtained in cells incubated in the absence of peptide (2008 \pm 55 d.p.m. per 20000 cells, $n=40$ from three subjects). One-way ANOVA: (A) GLP-1, $P=0.035$; insulin, $P=0.002$; (B) Ex-4, $P<0 \cdot 0001$; Ex-9, $P=0 \cdot 050$. LSD test vs control: ${ }^{*} P<0 \cdot 05,+P<0 \cdot 01$, $\S P<0 \cdot 0001$. 
muscle. The GLP-1 dose-response of glycogen synthesis was similar to that of insulin, with an $\mathrm{ED}_{50}$ of about $10^{-11} \mathrm{~mol} / \mathrm{l}$. At this submaximal concentration, the combined effect of both peptides on both glycogen synthesis and glycogen synthase a activity was additive, whereas at $10^{-10} \mathrm{~mol} / \mathrm{l}$ no further increment was detected, indicating that GLP-1 may share the insulinsignaling pathway at some post-receptor level. These in vitro effects were previously observed in skeletal muscle from normal (Villanueva-Peñacarrillo et al. 1994) and diabetic (Morales et al. 1997) rats, mice (O'Harte et al. 1997), and also in the rat myocyte cell line L6 (Yang et al. 1998), rat adipocytes (Oben et al. 1991, Miki et al. 1996, Perea et al. 1997) and mice adipocyte cell line 3T3-L1 (Egan et al. 1994). The activating action of GLP-1 on glycogen synthesis and synthase $a$ activity in human myotubes was maintained after $48 \mathrm{~h}$ exposure to the peptide, which supports the long-term therapeutic value of GLP-1.

This action of GLP-1 in muscle is probably being exerted through specific receptors (Delgado et al. 1995, Yang et al. 1998), with a signaling pathway (Villanueva-Peñacarrillo et al. 1994, Delgado et al. 1995, Alcántara et al. 1997, Yang et al. 1998) likely different from the pancreatic one (Thorens 1992). In human myocytes, we have detected either no effect, or a significant decrease in the cellular cAMP content, depending on the time cells had been in the presence of GLP-1 and absence of the phosphodiesterase inhibitor IBMX. This is in accordance not only with our previous observations in rat skeletal muscle (Villanueva-Peñacarrillo et al. 1994, Delgado et al. 1995, Alcántara et al. 1997) but also with those from other investigators in L6 myocytes (Yang et al. 1998). The same has been proposed for the GLP-1 receptor in the liver (Valverde et al. 1994, Alcántara et al. 1997) and in adipose cells (Miki et al. 1996, Montrose-Rafizadeh et al. 1997), where the peptide activates glycogen synthesis and lipid metabolism respectively, as either no change or a reduction in the cellular cAMP content by GLP-1 has been detected.

Further support for a different kind of GLP-1 receptor in those extrapancreatic tissues is furnished by the present results in human myotubes. In these cells, GLP-1, like insulin, induced the immediate hydrolysis of GPIs indicating the generation of IPGs - with a global dynamic similar to that previously detected not only in BC3H-1 myocytes (Galera et al. 1996) but also in a hepatoma cell line (Trapote et al. 1996) and in rat hepatocytes and adipocytes (Márquez et al. 1998), suggesting a role for IPGs in the immediate post-receptor mechanism leading to the GLP-1 actions.

Although our previous study in rat skeletal muscle, and in hepatocytes, documented an effect of Ex-9, antagonistic to that of GLP-1 (Alcántara et al. 1997), we have found in this work that, in human muscle cells, this peptide acts as an agonist by stimulating glycogen synthesis and glycogen synthase a activity; also, Ex-9 induced - although only within the first minutes of incubation in the absence of IBMX - a small but clear increase in cellular cAMP, in contrast to GLP-1 and Ex-4 by which no change or a reduction was detected. This agonistic action of Ex-9 in human myotubes is in accordance with the work of Yang et al. (1998) in L6 myocytes and that of MontroseRafizadeh et al. (1997) in 3T3-L1 adipocytes, all of which add further evidence for a GLP-1 receptor in the skeletal muscle, different from that in the pancreas.

The presence of these in vivo extrapancreatic effects of GLP-1, when intravenously administered, has been suggested in man, normal and diabetic (Gutniak et al. 1992, D'Alessio et al. 1994, 1995, Shalev et al. 1998), and also in depancreatized dogs (Sandhu et al. 1999) and diabetic rats (Mizuno et al. 1997), but its relevance is questioned by other studies on healthy humans (Toft-Nielson et al. 1996, Orskov et al. 1996, Larsson et al. 1997, Ryan et al. 1998), type 2 diabetic patients (Ahren et al. 1997, Vella et al. 2000) and insulin-dependent diabetic dogs (Freyse et al. 1999). Still, a recent work (Vella et al. 2001) performed in type 1 diabetic subjects has demonstrated that in the presence of hyperglycemia, hyperinsulinemia and enterally delivered glucose, GLP-1 does not modify splanchnic but increases total body glucose uptake, the skeletal muscle being, most probably, responsible for it. Due to the hormone interactions, in some of the published work it has been difficult to disclose an in vivo direct effect of GLP-1 on glucose metabolism; nevertheless, the in vitro results, including the present, preclude a direct action of GLP-1 on extrapancreatic tissues participating in the glucose homeostasis.

\section{Acknowledgements}

This work was supported by grants from the Ministerio de Sanidad y Consumo (FIS 98/1230) and Educación y Cultura (PM 99/0076), Spain. We thank the Departments of General Surgery and Orthopedics, Fundación Jiménez Díaz, for the tissue samples supply, E. Martín-Crespo for excellent technical assistance, and Mark Davis for proofreading the manuscript. M.A.L. and A.R. are Research fellows from the Ministerio de Educación y Cultura, and N.G. and L.M. are from Fundación Conchita Rábago de Jiménez Díaz.

\section{References}

Ahren B, Larsson H \& Holst JJ 1997 Effects of glucagon-like peptide-1 on islet function and insulin sensitivity in noninsulindependent diabetes mellitus. Journal of Clinical Endocrinology and Metabolism 82 473-478.

Alcántara AI, Morales M, Delgado E, Lopez-Delgado MI, Clemente F, Luque MA, Malaisse WJ, Valverde I \& Villañueva-Penacarrillo ML 1997 Exendin-4 agonist and exendin(9-39)amide antagonist of the GLP-1(7-36)amide effects in liver and muscle. Archives of Biochemistry and Biophysics 341 1-7. 
Blau HM \& Webster C 1981 Isolation and characterization of human muscle cells. PNAS 78 L5623-L5627.

Cámara J, Galera C, Valverde I \& Malaisse WJ 1991 Relationship between D-glucose oxidation and glycolysis in tumoral pancreatic islet cells with either rapid or decreased cell growth. Diabetes $\mathbf{1 7}$ 67-71.

Cancelas J, Villanueva-Peñacarrillo ML, Valverde I \& Malaisse WJ 2001a Suppression by exendin(9-39)amide of glucagon-like peptide 1 insulinotropic action in rats infused with the dimethyl ester of succinic acid. Endocrine 15 283-285.

Cancelas J, Villanueva-Peñacarrillo ML, Valverde I \& Malaisse WJ $2001 b$ Synergistic insulinotropic effects of succinic acid dimethyl ester and exendin-4 in anaesthetized rats. International Journal of Molecular Medicine 8 269-271.

Cuendet GS, Ernest G, Loten BJ \& Renold A 1976 Decreased basal, noninsulin-stimulated glucose uptake and metabolism by skeletal soleus muscle isolated from obese-hyperglycemic $(\mathrm{ob} / \mathrm{ob})$ mice. Journal of Clinical Investigation 58 1078-1088.

D’Alessio DA, Kahn SE, Leusner CR \& Ensinck JW 1994 Glucagon-like peptide 1 enhances glucose tolerance both by stimulation of insulin release and by increasing insulin-independent glucose disposal. Journal of Clinical Investigation 93 2263-2266.

D'Alessio DA, Prigeon RL \& Ensinck JW 1995 Enteral enhancement of glucose disposition by both insulin-dependent and insulinindependent processes. A physiological role of glucagon-like peptide I. Diabetes 44 1433-1437.

Delgado E, Luque MA, Alcántara A, Trapote MA, Clemente F, Galera C, Valverde I \& Villanueva-Peñacarrillo ML 1995 Glucagon-like peptide-1 binding to rat skeletal muscle. Peptides $\mathbf{1 6}$ 225-229.

Egan JM, Montrose-Rafizadeh C, Wang YH, Bernier M \& Roth J 1994 Glucagon-like peptide-1(7-36) amide (GLP-1) enhances insulin-stimulated glucose metabolism in 3T3-L1 adipocytes: one of several potential extrapancreatic sites of GLP-1 action. Endocrinology 135 2070-2075.

Fleig WE, Noether-Fleig G, Fussgaenger R \& Ditschuneit H 1984 Modulation by a sulfonylurea of insulin-dependent glycogenesis, but not of insulin binding, in cultured rat hepatocytes. Diabetes $\mathbf{3 3}$ 285-290.

Freyse EJ, Knospe S, Becher T, El Hag O, Goke B \& Fischer U 1999 Glucagon-like peptide-1 has no insulin-like effects in insulindependent diabetic dogs maintained normoglycemic and normoinsulinemic. Metabolism 48 134-137.

Galera C, Clemente F, Alcántara A, Trapote MA, Perea A, López-Delgado MI, Villanueva-Peñacarrillo ML \& Valverde I 1996 Inositolphosphoglycans and diacylglycerol are possible mediators in the GLP-1(7-36)amide glycogenic effect in BC3H-1 myocytes. Cell Biochemistry and Function 14 43-48.

Gerhardt W 1983 Creatine kinase. In Methods of Enzymatic Analysis, pp 508-518. Ed. HU Bergmeyer. New York: Academic Press.

Gutniak M, Orskov C, Holst JJ, Ahren B \& Efendic S 1992 Antidiabetogenic effect of glucagon-like peptide-1 (7-36)amide in normal subjects and patients with diabetes mellitus. New England Journal of Medicine 326 1316-1322.

Henry RR, Abrams L, Nikoulina S \& Ciaraldi TP 1995 Insulin action and glucose metabolism in nondiabetic control and NIDDM subjects. Comparison using human skeletal muscle cell cultures. Diabetes 44 936-946.

Hohorst H-J 1965 L(+)lactate determination with lactic dehydrogenase and DPN. In Methods of Enzymatic Analysis, pp 266-270. Ed. HU Bergmeyer. New York: Academic Press.

Hue L, Bontemps F \& Hers HG 1975 The effect of glucose and of potassium ions on the interconversion of glycogen phosphorylase and of glycogen synthethase in isolated rat liver preparation. Biochemical Journal 152 105-114.

Larsson H, Holst JJ \& Ahren B 1997 Glucagon-like peptide-1 reduces hepatic glucose production indirectly through insulin and glucagon in humans. Acta Physiologica Scandinavica $160413-422$.
Márquez L, Trapote MA, Luque MA, Alcántara AI, Valverde I \& Villanueva-Peñacarrillo ML 1998 Inositolphosphoglycans possibly mediate the GLP-1 effects on rat liver and adipose tissue. Cell Biochemistry and Function 16 51-56.

Mérida E, Delgado E, Molina LM, Villanueva-Peñacarrillo ML \& Valverde I 1993 Presence of glucagon and glucagon-like peptide-1(7-36)amide receptors in solubilized membranes of human adipose tissue. Journal of Clinical Endocrinology and Metabolism 77 1654-1657.

Miki H, Namba M, Nishimura T, Mineo I, Matsumura T, Miyagawa J, Nakajima H, Kuwajima M, Hanafusa T \& Matsuzawa Y 1996 Glucagon-like peptide-1(7-36)amide enhances insulin-stimulated glucose uptake and decreases intracellular cAMP content in isolated rat adipocytes. Biochimica et Biophysica Acta 1312 132-136.

Mizuno A, Kuwajima M, Ishida K, Noma Y, Murakami T, Tateishi K, Sato I \& Shima K 1997 Extrapancreatic action of truncated glucagon-like peptide-I in Otsuka Long-Evans Tokushima Fatty rats, an animal model for non-insulin-dependent diabetes mellitus. Metabolism 46 745-749.

Montrose-Rafizadeh C, Egan JM \& Roth J 1994 Incretin hormones regulate glucose-dependent insulin secretion in RIN 1046-38 cells: mechanisms of action. Endocrinology 135 589-594.

Montrose-Rafizadeh C, Yang H, Wang Y, Roth J, Montrose MH \& Adams LG 1997 Novel signal transduction and peptide specificity of glucagon-like peptide receptor in 3T3-L1 adipocytes. Journal of Cellular Physiology 172 275-283.

Morales M, López-Delgado MI, Alcántara A, Luque MA, Clemente F, Márquez L, Puente J, Viñambres C, Malaisse WJ, Villanueva-Peñacarrillo ML \& Valverde I 1997 Preserved GLP-1 effects on glycogen synthase $a$ activity and glucose metabolism in isolated hepatocytes and skeletal muscle from diabetic rats. Diabetes 46 1264-1269.

O'Harte FP, Gray AM, Abdel-Wahab YH \& Flatt PR 1997 Effects of non-glycated and glycated glucagon-like peptide-1(7-36) amide on glucose metabolism in isolated mouse abdominal muscle. Peptides 18 1327-1333.

Oben J, Morgan L, Fletcher J \& Marks V 1991 Effect of the enteropancreatic hormones, gastric inhibitory polypeptide and glucagonlike polypeptide-1(7-36) amide, on fatty acid synthesis in explants of rat adipose tissue. Journal of Endocrinology 130 267-272.

Orskov L, Holst JJ, Moller J, Orskov C, Moller N, Alberti KG \& Schmitz O 1996 GLP-1 does not acutely affect insulin sensitivity in healthy man. Diabetologia 39 1227-1232.

Perea A, Viñambres C, Clemente F, Villanueva-Peñacarrillo ML \& Valverde I 1997 GLP-1(7-36)amide effects on glucose transport and metabolism in rat adipose tissue. Hormone and Metabolic Research 29 417-421.

Ruiz-Grande C, Alarcón C, Mérida E \& Valverde I 1992 Lipolytic action of glucagon-like peptides in isolated rat adipocytes. Peptides 13 13-16.

Ryan AS, Egan JM, Habener JF \& Elahi D 1998 Insulinotropic hormone glucagon-like peptide-1-(7-37) appears not to augment insulin-mediated glucose uptake in young men during euglycemia. Journal of Clinical Endocrinology and Metabolism 83 2399-2404.

Saltiel AR, Fox JA, Sherline P \& Cuatrecasas P 1986 Insulinstimulated hydrolysis of a novel glycolipid generates modulators of cAMP phosphodiesterase. Science 233 967-972.

Sandhu H, Wiesenthal SR, MacDonald PE, McCall RH, Tchipashvili V, Rashid S, Satkunarajah M, Irwin DM, Shi ZQ, Brubaker PL, Wheeler MB, Vranic M, Efendic S \& Giacca A 1999 Glucagonlike peptide 1 increases insulin sensitivity in depancreatized dogs. Diabetes 48 1045-1053.

Shalev A, Ninnis R \& Keller U 1998 Effects of glucagon-like peptide 1 (7-36 amide) on glucose kinetics during somatostatin-induced suppression of insulin secretion in healthy men. Hormone Research 49 $221-225$ 
Thorens B 1992 Expression cloning of the pancreatic beta cell receptor for the gluco-incretin hormone glucagon-like peptide 1. PNAS $\mathbf{8 9}$ $8641-8645$

Toft-Nielson M, Madsbad S \& Holst JJ 1996 The effect of glucagonlike peptide I (GLP-I) on glucose elimination in healthy subjects depends on the pancreatic glucoregulatory hormones. Diabetes $\mathbf{4 5}$ 552-556.

Trapote MA, Clemente F, Galera C, Morales M, Alcántara A, LópezDelgado MI, Villanueva-Peñacarrillo ML \& Valverde I 1996 Inositolphosphoglycans implicated in the GLP-1(7-36)amide action in the liver. Journal of Endocrinological Investigation 19 114-118.

Valverde I, Mérida E, Delgado E, Trapote MA \& VillanuevaPeñacarrillo ML 1993 Presence and characterization of glucagonlike peptide-1(7-36)amide receptors in solubilized membranes of rat adipose tissue. Endocrinology 132 75-79.

Valverde I, Morales M, Clemente F, López-Delgado MI, Delgado E, Perea A \& Villanueva-Peñacarrillo ML 1994 Glucagon-like peptide 1: a potent glycogenic hormone. FEBS Letters 349 313-316.

Vella A, Shah P, Basu R, Basu A, Holst JJ \& Rizza RA 2000 Effect of glucagon-like peptide 1(7-36) amide on glucose effectiveness and insulin action in people with type 2 diabetes. Diabetes 49 611-617.
Vella A, Shah P, Basu R, Basu A, Camilleri M, Schwenk FW, Holst JJ \& Rizza RA 2001 Effect of glucagon-like peptide-1(7-36)-amide on initial splanchnic glucose uptake and insulin action in humans with type 1 diabetes. Diabetes 50 565-572.

Villanueva-Peñacarrillo ML, Alcántara AI, Clemente F, Delgado E \& Valverde I 1994 Potent glycogenic effect of GLP-1(7-36) $\mathrm{NH}_{2}$ in rat skeletal muscle. Diabetologia 37 1163-1166.

Villanueva-Peñacarrillo ML, Delgado E, Trapote MA, Alcántara A, Clemente F, Luque MA, Perea A \& Valverde I 1995a Glucagonlike peptide-1 binding to rat hepatic membranes. Journal of Endocrinology 146 183-189.

Villanueva-Peñacarrillo ML, Delgado E, Vicent D, Mérida E, Alcántara AI \& Valverde I 1995b GLP-1(7-36)amide binding in skeletal muscle membranes from streptozotocin diabetic rats. Endocrine 3 685-687.

Yang H, Egan JM, Wang Y, Moyes CD, Roth J, Montrose MH \& Montrose-Rafizadeh C 1998 GLP-1 action in L6 myotubes is via a receptor different from the pancreatic GLP-1 receptor. The American Journal of Physiology 275 C675-C683.

Received in final form 16 January 2002 Accepted 5 February 2002 